\author{
Dariusz Sokołowski \\ https://orcid.org/0000-0003-0361-7017 \\ Uniwersytet Mikołaja Kopernika w Toruniu \\ Wydział Nauk o Ziemi i Gospodarki Przestrzennej \\ Katedra Gospodarki Przestrzennej i Turyzmu \\ sokol@umk.pl
}

\title{
MIASTA ZDEGRADOWANE W WOJEWÓDZTWIE ŁÓDZKIM W KOŃCU I DEKADY XXI WIEKU ${ }^{1}$
}

\begin{abstract}
Abstrakt: Miasta zdegradowane są ważnym składnikiem wiejskiej sieci osadniczej. Celem opracowania jest charakterystyka miejscowości położonych w obecnych granicach województwa łódzkiego, które utraciły status miasta, a także odpowiedź na pytanie, czy są na tym terenie jednostki osadnicze mające realne szanse na uzyskanie w niedalekiej przyszłości tego statusu. Zbiór miejscowości omówiony w artykule obejmuje wszystkie byłe miasta, które zostały zdegradowane przed $2010 \mathrm{r}$. Badania pokazały, że na obszarze województwa łódzkiego jest ich relatywnie dużo (aż 73), co jest konsekwencją dekretu carskiego, pozbawiającego w II połowie XIX w. praw miejskich wielu ówczesnych miast w granicach zaboru rosyjskiego.
\end{abstract}

Słowa kluczowe: miasta zdegradowane, byłe miasta, prawa miejskie, sieć osadnicza, województwo łódzkie.

\section{DEGRADED TOWNS IN THE ŁÓDZKIE VOIVODESHIP IN THE END OF THE FIRST DECADE OF XXI CENTURY}

\begin{abstract}
Former cities are an important component of the rural settlement network. The purpose of the study is to characterize the villages located within the current borders of the Łódź Voivodeship, which have lost their city status, as well as the answer to the question whether there are villages in this area with real chances of obtaining this status in the near future. The set of villages discussed in the article includes all former cities that were degraded before 2010. Research has shown that there are relatively many (73) such villages in the Łódź Voivodeship, which is a consequence of the tsarist decree depriving many cities of their rights within the Russian partition in the second half of the $19^{\text {th }}$ century.
\end{abstract}

Keywords: city, recreational space, quality of life, local policy, Szczecin.

\section{WSTĘP}

Miasta zdegradowane są ważnym składnikiem wiejskiej sieci osadniczej z uwagi m.in. na to, że:

- zaliczają się do grupy największych pod względem zaludnienia miejscowości wiejskich;

- posiadają zwykle dobrze rozwinięte więzi z zapleczem, stanowiąc silne, w skali lokalnej, miejsca centralne;

- są zwykle dobrze wyposażone w urządzenia infrastruktury technicznej i społecznej;

- większość z nich ma miejski układ przestrzenny;

- są często miejscowościami uprzemysłowionymi lub wielofunkcyjnymi, lepiej rozwiniętymi od większości pozostałych wsi z punktu widzenia bazy ekonomicznej;

- część miejscowości tej kategorii ma szanse formalnoprawnego zaliczenia do kategorii miast.

Niemal corocznie od 1980 r. (z wyjątkiem lat: 1981, 1985, 1995, 1999 i 2002) kategoria miast jest w Polsce po- większana o jedną bądź kilka miejscowości. Od roku 1980 do 1 stycznia 2010 r. prawa miejskie uzyskało 101 miejscowości, $\mathrm{w}$ tej liczbie $3 / 4$ jednostek to dawne miasta zdegradowane. Jakkolwiek współcześnie z nadaniem praw miejskich nie wiążą się szczególne przywileje (por. Drobek, 1999; Sokołowski, 2008), to jednak przez liczne społeczności lokalne sprawa traktowana jest jako prestiżowa, czego konsekwencją jest wiele przypadków wystąpienia z wnioskiem o nadanie praw miejskich. Znaczna ich część kończy się powodzeniem; jako przykład można podać ostatnie nadania praw miejskich. 1 stycznia 2010 r. uzyskało je sześć miejscowości: Kołaczyce i Przecław w województwie podkarpackim, Łaszczów w województwie lubelskim, Radłów w województwie małopolskim, Szepietowo w województwie podlaskim i Tychowo w województwie zachodniopomorskim². Trzy pierwsze i ostatnie z wymienionych posiadały w przeszłości prawa miejskie przez długi okres (od około 
320 do blisko 560 lat), a Radłów był uznawany na przełomie XIX i XX w. za miasteczko (kategoria miejscowości z niektórymi tylko atrybutami miejskości w byłym zaborze austriackim). Rok wcześniej było takich miejscowości pięć: Bobowa i Szczucin w województwie małopolskim, Krynki i Michałowo w województwie podlaskim oraz Brzostek w podkarpackim; wszystkie posiadały w przeszłości prawa miejskie.

W województwie łódzkim w ostatnich trzech dekadach pięć miejscowości uzyskało (odzyskało) prawa miejskie: Drzewica w 1987 r., Działoszyn i Kamieńsk w 1993, Rzgów w 2006 i Wolbórz w 2011 r. Nie oznacza to, że możliwości zostały już wyczerpane i położone w centrum kraju województwo nie ma większej liczby kandydatów na miasta.

Celem opracowania jest charakterystyka tytułowego zbioru miejscowości, a także odpowiedź na pytanie, czy są na terenie województwa łódzkiego miejscowości mające realne szanse na uzyskanie $\mathrm{w}$ niedalekiej przyszłości statusu miasta.

\section{ZBIÓR MIAST ZDEGRADOWANYCH W WOJEWÓDZTWIE ŁÓDZKIM}

Na terenie województwa łódzkiego znajduje się znaczna liczba miast zdegradowanych, co jest konsekwencją czynnika historycznego: cały omawiany obszar znajdował się od 1815 do 1918 r. w granicach zaboru rosyjskiego (Królestwo Kongresowe) i przechodził podobne koleje losu. Najważniejszym wydarzeniem z punktu widzenia osadnictwa był dekret carski pozbawiający w latach 1869-1870 praw miejskich większość ówczesnych miast. Abstrahując od rzeczywistych powodów takiego postępowania, z dzisiejszej perspektywy istotne znaczenie ma fakt przetrzebienia sieci miejskiej, która do obecnych czasów nie została w pełni uzupełniona. Nie chodzi przy tym o „naprawianie krzywd dziejowych" wszystkim zdegradowanym miasteczkom: w przypadku wielu $\mathrm{z}$ nich nie jest to już celowe. Chodzi raczej o identyfikację tych, które z uwagi na określone parametry kwalifikują się do kategorii małych miast, nie ustępując de facto pod większością względów tym, które prawa miejskie w ostatnim czasie otrzymały.

Na obszarze województwa łódzkiego zidentyfikowano 73 byłe miasta, które można zaliczyć do następujących kategorii:

- byłe miasto, obecnie wieś gminna;

- byłe miasto, obecnie wieś niebędąca siedzibą gminy;

- byłe miasto (lub osiedle), obecnie stanowiące część innego miasta;

- byłe osiedle (w rozumieniu praw osiedlowych, jakie obowiązywały w PRL w latach 1954-1972), obecnie wieś gminna.

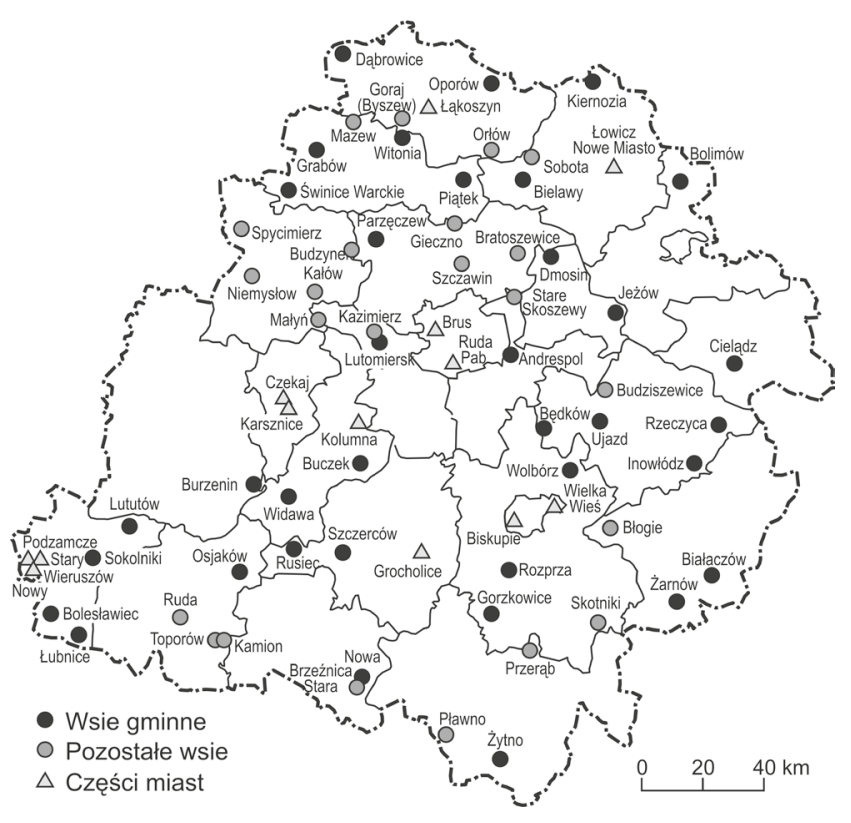

Rys. 1. Miasta zdegradowane w województwie łódzkim według statusu administracyjnego (stan na 1.01.2010)

Źródło: opracowanie własne na podstawie danych jak w tab. 1

Tabela 1. Wykaz miast zdegradowanych w województwie łódzkim

z uwzględnieniem ich statusu prawnego (stan na 1.01.2010)

\begin{tabular}{|l|c|c|}
\hline \multicolumn{1}{|c|}{ Miejscowość } & Obecny status & Powiat \\
\hline $\begin{array}{l}\text { Andrespol } \\
\text { (byłe osiedle) }\end{array}$ & wieś gminna & łódzki \\
\hline Będków & wieś gminna & tomaszowski \\
\hline Białaczów & wieś gminna & opoczyński \\
\hline Bielawy & wieś gminna & łowicki \\
\hline Błogie & wieś w gm. Mniszków & opoczyński \\
\hline Bolesławiec & wieś gminna & wieruszowski \\
\hline Bolimów & wieś gminna & skierniewicki \\
\hline Bratoszewice & wieś w gm. Stryków & zgierski \\
\hline Buczek & wieś gminna & łaski \\
\hline Budziszewice & w gm. Żelechlinek & tomaszowski \\
\hline Budzynek & wieś w gm. Dalików & poddębicki \\
\hline Burzenin & wieś gminna & sieradzki \\
\hline Cielądz & wieś gminna & rawski \\
\hline Dąbrowice & wieś gminna & kutnowski \\
\hline Dmosin & wieś gminna & brzeziński \\
\hline Gieczno & wieś w gm. Zgierz & zgierski \\
\hline $\begin{array}{l}\text { Goraj } \\
\text { (obecnie Byszew) }\end{array}$ & wieś w gm. Kutno & kutnowski \\
\hline Gorzkowice & wieś gminna & piotrkowski \\
\hline Grabów & wieś gminna gminna & tomamaszowski \\
\hline Inowłódz & & \\
\hline
\end{tabular}




\begin{tabular}{|c|c|c|}
\hline Miejscowość & Obecny status & Powiat \\
\hline 1 & 2 & 3 \\
\hline Jeżów & wieś gminna & brzeziński \\
\hline Kałów & wieś w gm. Poddębice & poddębicki \\
\hline Kamion & wieś w gm. Wierzchlas & wieluński \\
\hline Kazimierz & wieś w gm. Lutomiersk & pabianicki \\
\hline Kiernozia & wieś gminna & łowicki \\
\hline Lutomiersk & wieś gminna & pabianicki \\
\hline Lututów & wieś gminna & wieruszowski \\
\hline Łubnice & wieś gminna & wieruszowski \\
\hline Małyń & wieś w gm. Zadzim & poddębicki \\
\hline Mazew & wieś w gm. Daszyna & łęczycki \\
\hline Niemysłów & wieś w gm. Poddębice & poddębicki \\
\hline Nowa Brzeźnica & wieś gminna & pajęczański \\
\hline Oporów & wieś gminna & kutnowski \\
\hline Orłów & wieś w gm. Bedlno & kutnowski \\
\hline Osjaków & wieś gminna & wieluński \\
\hline Parzęczew & wieś gminna & zgierski \\
\hline Piątek & wieś gminna & łęczycki \\
\hline Pławno & wieś w gm. Gidle & radomszczański \\
\hline Przerąb & wieś w gm. Masłowice & radomszczański \\
\hline Rozprza & wieś gminna & piotrkowski \\
\hline Ruda & wieś w gm. Wieluń & wieluński \\
\hline Rusiec & wieś gminna & bełchatowski \\
\hline Rzeczyca & wieś gminna & tomaszowski \\
\hline Skotniki & $\begin{array}{c}\text { wieś } \\
\text { w gm. Aleksandrów }\end{array}$ & piotrkowski \\
\hline Sobota & wieś w gm. Bielawy & łowicki \\
\hline Sokolniki & wieś gminna & wieruszowski \\
\hline Spycimierz & wieś w gm. Uniejów & poddębicki \\
\hline $\begin{array}{l}\text { Stara } \\
\text { Brzeźnica }\end{array}$ & $\begin{array}{c}\text { wieś } \\
\text { w gm. Nowa Brzeźnica }\end{array}$ & pajęczański \\
\hline $\begin{array}{l}\text { Stare } \\
\text { Skoszewy }\end{array}$ & $\begin{array}{c}\text { wieś } \\
\text { w gm. Nowosolna }\end{array}$ & $\begin{array}{c}\text { łódzki } \\
\text { wschodni }\end{array}$ \\
\hline Szczawin & wieś w gm. Zgierz & zgierski \\
\hline Szczerców & wieś gminna & bełchatowski \\
\hline Świnice Warckie & wieś gminna & łęczycki \\
\hline Toporów & wieś w gm. Wierzchlas & wieluński \\
\hline Ujazd & wieś gminna & tomaszowski \\
\hline Widawa & wieś gminna & łaski \\
\hline Witonia & wieś gminna & łęczycki \\
\hline Wolbórz & wieś gminna & piotrkowski \\
\hline Żarnów & wieś gminna & opoczyński \\
\hline Żytno & wieś gminna & radomszczański \\
\hline
\end{tabular}

Źródło: opracowanie własne na podstawie: Drobek (1999); Miasta polskie... (1967); Statystyka miast... (1967).

Pierwsza z wymienionych kategorii jest reprezentowana przez 36 jednostek, do drugiej kategorii zaliczono 23 jednostki ${ }^{3}$, trzecia liczy 13 jednostek ${ }^{4}$, a czwarta jedną.
Rysunek 1 ukazuje wszystkie zidentyfikowane byłe miasta, a w tab. 1 pominięto te, które stanowią obecnie część innej miejscowości.

\section{ZMIANY ILOŚCIOWE W SIECI MIAST}

Bezpośrednio za zmiany liczby miast w czasie odpowiedzialne są decyzje formalnoprawne, które w przeszłości prowadziły do tworzenia, łączenia lub degradacji miast.

Byłe miasta włączone $\mathrm{w}$ granice innych miast nie utraciły miejskiego statusu, pomimo utraty samodzielności, dlatego też nie stanowią one przedmiotu niniejszego badania. Miejscowości zdegradowane można podzielić na te, które odzyskały już prawa miejskie i te, które ich dotychczas nie odzyskały. Pierwsze z nich stanowią interesujący materiał porównawczy, natomiast przedmiotem badania są miejscowości z ostatniej grupy.

Na szczególną uwagę zasługują miejscowości zdegradowane w latach 1869-1870 na mocy odpowiedniego ukazu carskiego, który obniżył range ponad 300 miast w Królestwie Polskim. W województwie łódzkim prawa miejskie straciły wówczas 42 miasta, a ogólna liczba miast $\mathrm{w}$ tym województwie zmalała z 63 do 21. Części spośród tych miejscowości przywrócono prawa miejskie wkrótce po odzyskaniu przez Polskę niepodległości, jednak 24 nadal pozostają wsiami (tab. 2, rys. 2). Ta kategoria miejscowości ma duże znaczenie z punktu widzenia identyfikacji potencjalnych miast, ponieważ radykalnie przeprowadzona akcja degradacji, obejmująca $2 / 3$ ogólnej liczby miast, w przypadku niektórych została przeprowadzona "na wyrost". Zdegradowano wówczas do rzędu osad

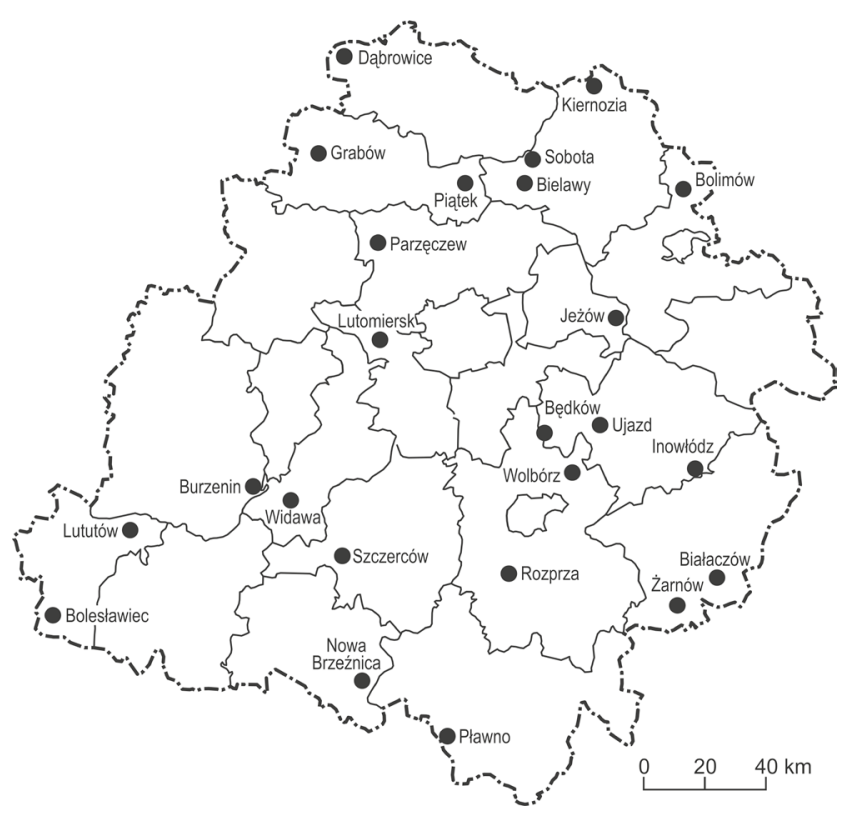

Rys. 2. Miasta zdegradowane w województwie łódzkim pozbawione praw miejskich $\mathrm{w}$ latach 1869-1870

Źródło: opracowanie własne na podstawie różnych danych 
Tabela 2. Wybrane cechy miast zdegradowanych w województwie łódzkim

\begin{tabular}{|c|c|c|c|c|c|}
\hline \multirow{2}{*}{ Miejscowość } & \multicolumn{2}{|c|}{ Prawa miejskie } & \multirow{2}{*}{$\begin{array}{c}\text { Ludność } \\
\text { nierolnicza (\%) }\end{array}$} & \multirow{2}{*}{ Typ funkcjonalny } & \multirow{2}{*}{ Typ zabudowy } \\
\hline & uzyskanie & utrata & & & \\
\hline 1 & 2 & 3 & 4 & 5 & 6 \\
\hline Andrespol (b. osiedle) & $1963 \mathrm{r}$. & $1972 \mathrm{r}$. & 99 & $\mathrm{C}$ & $\mathrm{D}$ \\
\hline Będków & 1453 & $1870 \mathrm{r}$. & 81 & $\mathrm{~A}$ & $\mathrm{C}$ \\
\hline Białaczów & XIII w. lub 1456 r. & $1869 \mathrm{r}$. & 76 & $\mathrm{~A}$ & $\mathrm{D}$ \\
\hline Bielawy & $1403 \mathrm{r}$ & $1870 \mathrm{r}$. & 5 & $\mathrm{~A}$ & $\mathrm{C}$ \\
\hline Błogie & $?$ & $?$ & 50 & $\mathrm{~A}$ & $\mathrm{~B}$ \\
\hline Bolesławiec & $1269 \mathrm{r}$. & $1870 \mathrm{r}$. & 30 & $\mathrm{~B}$ & $\mathrm{C}$ \\
\hline Bolimów & $1370 \mathrm{r}$. & $1869 \mathrm{r}$. & 95 & $\mathrm{~A}$ & $\mathrm{~A}$ \\
\hline Bratoszewice & przed $1458 \mathrm{r}$. & $?$ & 87 & $\mathrm{~B}$ & $\mathrm{D}$ \\
\hline Buczek & $1549 \mathrm{r}$ & XVII w. & 27 & $\mathrm{~A}$ & $\mathrm{~A}$ \\
\hline Budziszewice & $1358 \mathrm{r}$. & XVIII w. & 60 & B & $\mathrm{AD}$ \\
\hline Budzynek & $1454 \mathrm{r}$. & XVII w. & 2 & $\mathrm{~B}$ & $\mathrm{~A}$ \\
\hline Burzenin & $1378 \mathrm{r}$. & $1869 \mathrm{r}$. & 67 & $\mathrm{~A}$ & G \\
\hline Cielądz & $?$ & $?$ & 48 & B & A \\
\hline Dąbrowice & przed $1455 \mathrm{r}$. & $1870 \mathrm{r}$. & 50 & $\mathrm{~A}$ & $\mathrm{D}$ \\
\hline Dmosin & $1430 \mathrm{r}$ & II poł. XVI w. & 62 & $\mathrm{~B}$ & $\mathrm{~A}$ \\
\hline Gieczno & II poł. XVI w. & II poł. XVI w. & 82 & A & A \\
\hline Goraj (obecnie Byszew) & przed $1458 \mathrm{r}$. & poł. XVI w. & 7 & $\mathrm{~B}$ & $\mathrm{~B}$ \\
\hline Gorzkowice & 1494 r. & XVI w. & 89 & $\mathrm{~A}$ & $\mathrm{CD}$ \\
\hline Grabów & $1372 \mathrm{r}$. & $1870 \mathrm{r}$. & 8 & $\mathrm{~A}$ & $\mathrm{E}$ \\
\hline Inowłódz & XIV w. & $1870 \mathrm{r}$. & 93 & $\mathrm{~A}$ & $\mathrm{~A}$ \\
\hline Jeżów & $1334 \mathrm{r}$. & $1870 \mathrm{r}$. & 65 & $\mathrm{~A}$ & $\mathrm{C}$ \\
\hline Kałów & XV w. & $?$ & 18 & $\mathrm{C}$ & $\mathrm{B}$ \\
\hline Kamion & przed $1462 \mathrm{r}$. & XVI w. & 7 & $\mathrm{C}$ & $\mathrm{C}$ \\
\hline Kazimierz & przed $1288 \mathrm{r}$. & $1870 \mathrm{r}$. & 50 & $\mathrm{~B}$ & A \\
\hline Kiernozia & $1567 \mathrm{r}$. & $1870 \mathrm{r}$. & 50 & $\mathrm{~A}$ & $\mathrm{C}$ \\
\hline Lutomiersk & $1274 \mathrm{r}$. & $1870 \mathrm{r}$. & 70 & $\mathrm{~A}$ & $\mathrm{C}$ \\
\hline Lututów & 1405 i 1843 r. & 1720 i 1870 r. & 30 & A & G \\
\hline Łubnice & $1238 \mathrm{r}$. & XIII w. & 15 & $\mathrm{~B}$ & $\mathrm{~A}$ \\
\hline Małyń & $1549 \mathrm{r}$. & ok. 1654 r. & 50 & $\mathrm{~B}$ & $\mathrm{~A}$ \\
\hline Mazew & $1416 \mathrm{r}$. & lokacja nieudana & 45 & $\mathrm{~A}$ & $\mathrm{D}$ \\
\hline Niemysłów & przed $1563 \mathrm{r}$. & $?$ & 12 & $\mathrm{C}$ & $\mathrm{B}$ \\
\hline Nowa Brzeźnica & 1287 & $1870 \mathrm{r}$. & 20 & $\mathrm{~A}$ & $\mathrm{C}$ \\
\hline Orłów & przed $1387 \mathrm{r}$. & pocz. XIX w. & 22 & $\mathrm{~B}$ & A \\
\hline Osjaków & przed $1446 \mathrm{r}$. & XVII w. & 85 & $\mathrm{~A}$ & G \\
\hline Parzęczew & $1421 \mathrm{r}$. & $1870 \mathrm{r}$. & 89 & $\mathrm{~A}$ & $\mathrm{D}$ \\
\hline Piątek & przed $1339 \mathrm{r}$. & $1870 \mathrm{r}$. & 87 & $\mathrm{~A}$ & $\mathrm{C}$ \\
\hline Pławno & $1544 \mathrm{r}$. & $1870 \mathrm{r}$. & 95 & B & G \\
\hline Przerąb & $1786 \mathrm{r}$. & koniec XVIII w. & 21 & $\mathrm{~A}$ & C \\
\hline Rozprza & przed $1344 \mathrm{r}$. & $1870 \mathrm{r}$. & 87 & $\mathrm{~A}$ & $\mathrm{C}$ \\
\hline Ruda & XIII w. & XIV w. & 50 & $\mathrm{~B}$ & $\mathrm{D}$ \\
\hline Rusiec & przed $1609 \mathrm{r}$. & XVIII w. & 45 & $\mathrm{~A}$ & $E$ \\
\hline Rzeczyca & przed $1790 \mathrm{r}$. & $?$ & 19 & $\mathrm{~A}$ & $\mathrm{D}$ \\
\hline Skotniki & $?$ & $?$ & 50 & $\mathrm{~A}$ & $\mathrm{C}$ \\
\hline Sobota & przed $1393 \mathrm{r}$. & $1870 \mathrm{r}$. & 4 & $\mathrm{~B}$ & A \\
\hline
\end{tabular}




\begin{tabular}{|c|c|c|c|c|c|}
\hline Miejscowość & \multicolumn{2}{|c|}{ Prawa miejskie } & Ludność & Typ funkcjonalny & Typ zabudowy \\
\hline 1 & 2 & 3 & 4 & 5 & 6 \\
\hline Sokolniki & $1726 \mathrm{r}$. & koniec XVIII w. & 42 & $\mathrm{~A}$ & A \\
\hline Spycimierz & przed $1357 \mathrm{r}$. & $?$ & 18 & $\mathrm{C}$ & $\mathrm{C}$ \\
\hline Stara Brzeźnica & przed $1265 \mathrm{r}$. & $1287 \mathrm{r}$. & - & - & - \\
\hline Stare Skoszewy & $1426 \mathrm{r}$. & $1702 \mathrm{r}$. & 10 & B & A \\
\hline Szczawin & przed $1339 \mathrm{r}$. & $?$ & 96 & B & $\mathrm{D}$ \\
\hline Szczerców & przed $1364 \mathrm{r}$. & $1870 \mathrm{r}$. & 82 & A & C \\
\hline Świnice Warckie & przed $1458 \mathrm{r}$. & krótko po 1458 r. & 30 & $\mathrm{C}$ & B \\
\hline Toporów & przed $1464 \mathrm{r}$. & pocz. XVIII w. & 5 & B & B \\
\hline Ujazd & $1428 \mathrm{r}$. & $1870 \mathrm{r}$. & - & $\mathrm{A}$ & $\mathrm{CD}$ \\
\hline Widawa & $1388 \mathrm{r}$. & $1870 \mathrm{r}$. & 93 & $\mathrm{~A}$ & $C$ \\
\hline Witonia & przed $1728 \mathrm{r}$. & po $1764 \mathrm{r}$. & 60 & B & $\mathrm{D}$ \\
\hline Wolbórz & $1273 \mathrm{r}$. & $1870 \mathrm{r}$. & 94 & $\mathrm{~A}$ & C \\
\hline Żarnów & $1415 \mathrm{r}$. & $1869 \mathrm{r}$. & 68 & $\mathrm{~A}$ & $\mathrm{D}$ \\
\hline$\dot{Z}$ Żytno & $1441 \mathrm{r}$. & pocz. XVIII w. & 50 & $\mathrm{~A}$ & $\mathrm{D}$ \\
\hline
\end{tabular}

Zestawienie zawiera liczne rozbieżności w stosunku do danych NSP 1988. Typ funkcjonalny (kolumna 5) według charakteru wyposażenia w infrastrukturę społeczną: A - subokręgowy ośrodek usług, B - inny ośrodek usług niższego rzędu, C - pozostałe. Dominujący typ zabudowy (kolumna 6): A - jednodrożny zwarty, B - jednodrożny luźny, C - placowy, D - wielodrożny, E - rozproszony, G-miejski.

Źródło: Miasta polskie... (1967); Rosin (1959, 1971); Słownik geograficzny... (1880-1902); Statystyka miast... (1967); Stelmach, Malina, Tkocz, Żukowski (1990).

Tabela 3. Zmiany gęstości sieci miejskiej na obszarze województwa łódzkiego na tle Polski

\begin{tabular}{|l|c|c|c|c|}
\hline \multicolumn{2}{|c|}{ Wyszczególnienie } & Województwo łódzkie & Polska & Królestwo Polskie \\
\hline \multicolumn{2}{|l|}{ Powierzchnia w km² } & 18219 & 312700 & 128500 \\
\hline \multirow{2}{*}{ Liczba miast } & $1860 \mathrm{r}$. & 63 & - & 452 \\
\cline { 2 - 5 } & $1910 \mathrm{r}$. & 21 & - & 114 \\
\cline { 2 - 5 } & $2010 \mathrm{r}$. & 43 & - & - \\
\hline \multirow{2}{*}{$\begin{array}{l}\text { Obszar w km }{ }^{2} \text { przypadający na miasto } \\
\text { jedno }\end{array}$} & $1860 \mathrm{r}$. & 289 & - & 1127 \\
\cline { 2 - 5 } & $1910 \mathrm{r}$. & 868 & 346 & - \\
\hline \multirow{2}{*}{$\begin{array}{l}\text { Przeciętna odległość między } \\
\text { miastamia w km }\end{array}$} & $2010 \mathrm{r}$. & 424 & - & 16,9 \\
\cline { 2 - 5 } & $1860 \mathrm{r}$. & 17,0 & - & 33,6 \\
\cline { 2 - 5 }
\end{tabular}

a Obliczona za pomocą wzoru: $R=\sqrt{\frac{P}{N}}$, gdzie: $\mathrm{P}$ - powierzchnia obszaru w km², $\mathrm{N}$ - liczba miast.

Źródło: Powierzchnia i ludność... (2009), opracowanie własne.

wiejskich m.in. miasteczka względnie duże, liczące co najmniej 2000 mieszkańców (zob. tab. 4) i nieźle prosperujące, $\mathrm{w}$ przeciwieństwie do wcześniejszych degradacji (sprzed 1869 r.) dotyczących nieudanych lokacji bądź faktycznie upadłych miasteczek (niekiedy zniszczonych w czasie wojen i wyludnionych).

Omawiany dekret carski spowodował spadek gęstości sieci miejskiej, w wyniku którego obszar obsługiwany przez jedno miasto zwiększył się średnio z $289 \mathrm{~km}^{2}$ przed 1869 r. do $868 \mathrm{~km}^{2}$ w latach 1870-1918. W schyłkowym okresie zaborów była to powierzchnia mniejsza niż w całym Królestwie Polskim, co świadczy o odpowiednio większej gęstości sieci miejskiej utrzymanej w województwie łódzkim (tab. 3). Stanowiło to w pewnym stopniu konsekwencję rozwoju łódzkiego okręgu włókienniczego, który to rozwój uchronił przed degradacją kilka miast. Największa redukcja liczby miast nastapiła $w$ tym czasie $w$ powiatach łowickim i tomaszowskim (w każdym po trzy miasta), biorąc pod uwagę tylko miejscowości do dziś niebędące miastami. Wyróżnia się także, z uwzględnieniem wcześniejszych degradacji, powiaty łęczycki, poddębicki i tomaszowski, w których utraciło prawa miejskie po pięć miejscowości, a także kutnowski, piotrkowski, 
wieluński, wieruszowski i zgierski - po cztery miejscowości. W wyniku przeprowadzonej degradacji w latach 1869-1870 przeciętna odległość między miastami wzrosła w porównywanych latach z 17 do blisko $30 \mathrm{~km}$.

Istotne zagadnienie stanowią przyczyny ludnościowego, funkcjonalnego i ekonomicznego upadku miast. Pogorszenie się sytuacji wielu miasteczek było konsekwencją szybkiego rozwoju ośrodków konkurencyjnych, które zdołały w drugiej połowie XIX w. włączyć się w nurt kapitalistycznego uprzemysłowienia. W uprzywilejowanej sytuacji znalazły się także miasta położone przy trasie kolei żelaznej, która odgrywała wówczas rolę silnego stymulatora rozwoju.

\section{ZMIANY ZALUDNIENIA}

Obecnie sytuacja demograficzna miast zdegradowanych w województwie łódzkim jest bardzo zróżnicowana. Ich zaludnienie waha się od około 200 (Budzynek, Kałów, Kamion, Małyń, Stare Skoszewy) do blisko 3,3 tys. mieszkańców (Andrespol, Gorzkowice, Szczerców) (tab. 4, rys. 3). Liczne miejscowości nie osiągnęły dotychczas stanu zaludnienia z II połowy XIX w., co wskazuje, że znajdują się one w stanie regresu i świadczy o ich niskiej atrakcyjności, m.in. z powodu słabości bazy ekonomicznej. Takie natomiast miejscowości, jak Inowłódz czy Jeżów, notowały stały spadek zaludnienia w ciągu kilku ostatnich dziesięcioleci.

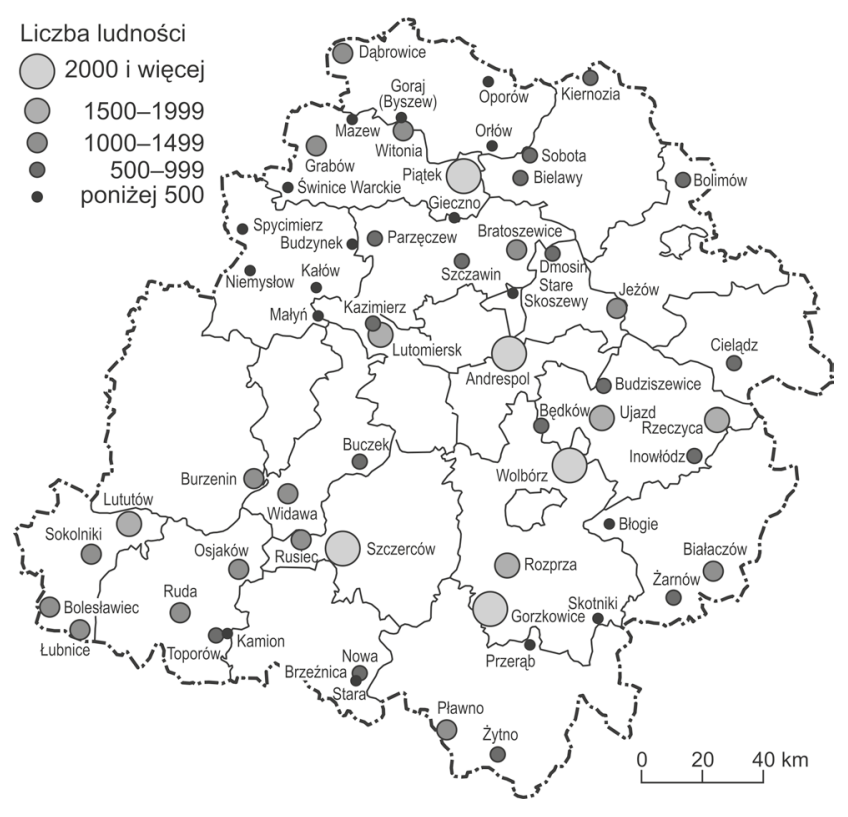

Rys. 3. Miasta zdegradowane w województwie łódzkim według zaludnienia (stan na ok. 2008 r.)

Źródło: opracowanie własne na podstawie różnych danych

Warto wspomnieć, że jednym ze współczesnych kryteriów przyznawania praw miejskich jest osiągnięcie przez miejscowość zaludnienia na poziomie co najmniej 2000 mieszkańców. Jakkolwiek w niektórych przypadkach wymóg ten nie jest przestrzegany (wystarczy wspomnieć Kołaczyce i Przecław spośród nowych nadań - liczące odpowiednio 1316 i 1400 mieszkańców), to liczbę

Tabela 4. Liczba mieszkańców miast zdegradowanych w województwie łódzkim w latach 1868-2008

\begin{tabular}{|l|c|c|c|c|c|c|c|}
\hline \multirow{2}{*}{\multicolumn{1}{c|}{ Miejscowość }} & \multicolumn{7}{c|}{ Rok } \\
\cline { 2 - 8 } & $1868^{\mathrm{a}}$ & 1890 & 1910 & 1950 & 1970 & 1988 & ok. 2008 \\
\hline Andrespol (b. osiedle) & 2 & 3 & 4 & 5 & 6 & 7 & 8 \\
\hline Będków & - & - & - & 1142 & 1942 & 2921 & 3359 \\
\hline Białaczów & 687 & 885 & 898 & - & - & 602 & 612 \\
\hline Bielawy & 1020 & 1059 & 2102 & 1446 & 1484 & 1319 & 1235 \\
\hline Błogie & 761 & 990 & - & - & - & 605 & 602 \\
\hline Bolesławiec & $313^{\mathrm{b}}$ & - & - & - & - & $222^{\mathrm{c}}$ & 322 \\
\hline Bolimów & 1301 & 1264 & 1951 & - & - & 856 & 937 \\
\hline Bratoszewice & 1097 & 2088 & 2342 & - & - & 841 & 930 \\
\hline Buczek & 470 & - & - & 795 & 1182 & 1139 & 1084 \\
\hline Budziszewice & 500 & - & - & - & - & 994 & 980 \\
\hline Budzynek & 500 & - & - & - & - & $887 \mathrm{c}$ & 880 \\
\hline Burzenin & $130^{\mathrm{b}}$ & - & - & - & - & $176^{\mathrm{c}}$ & 140 \\
\hline Cielądz & 833 & 838 & 1444 & 726 & 853 & 1079 & 989 \\
\hline Dąbrowice & $233^{\mathrm{b}}$ & - & - & - & - & 636 & 813 \\
\hline Dmosin & 1800 & 2431 & 3213 & 1769 & 1565 & 1205 & 802 \\
\hline Gieczno & 600 & - & - & - & - & 953 & 795 \\
\hline
\end{tabular}




\begin{tabular}{|c|c|c|c|c|c|c|c|}
\hline \multirow{2}{*}{ Miejscowość } & \multicolumn{7}{|c|}{ Rok } \\
\hline & $1868^{a}$ & 1890 & 1910 & 1950 & 1970 & 1988 & ok. 2008 \\
\hline 1 & 2 & 3 & 4 & 5 & 6 & 7 & 8 \\
\hline Gorzkowice & 457 & - & - & 1390 & 2003 & 3076 & 3416 \\
\hline Grabów & 1023 & 1838 & 1500 & 1681 & 1709 & 1356 & 1171 \\
\hline Inowłódz & 1037 & 1483 & 2192 & - & - & 913 & 795 \\
\hline Jeżów & 1340 & 2103 & 2673 & 1797 & 1573 & 1448 & 1341 \\
\hline Kałów & 385 & - & - & - & - & $194^{\mathrm{c}}$ & 162 \\
\hline Kamion & - & - & - & - & - & $161^{\mathrm{c}}$ & 154 \\
\hline Kazimierz & 380 & 678 & 784 & - & - & 694 & 721 \\
\hline Kiernozia & 468 & 440 & 387 & - & - & 931 & 948 \\
\hline Lutomiersk & 2133 & 2852 & 3007 & 1650 & 1680 & 1429 & 1429 \\
\hline Lututów & 536 & 1115 & 2168 & 1360 & 1338 & 1529 & 1450 \\
\hline Łubnice & 1155 & - & - & 1068 & 1112 & 1074 & 1139 \\
\hline Małyń & 435 & - & - & - & - & $211^{c}$ & 131 \\
\hline Mazew & 730 & - & - & - & - & $335^{c}$ & 304 \\
\hline Niemysłów & 615 & - & - & - & - & $390^{c}$ & 332 \\
\hline Nowa Brzeźnica & 1267 & 1684 & 1866 & - & - & 703 & 750 \\
\hline Oporów & 233 & - & - & - & - & 330 & 280 \\
\hline Osjaków & 867 & - & - & 798 & 908 & 1072 & 1236 \\
\hline Parzęczew & 1208 & 950 & 1218 & - & - & 675 & 672 \\
\hline Piątek & 2097 & 2287 & 3379 & 1683 & 2039 & 2134 & 2017 \\
\hline Pławno & 1444 & 2177 & 3591 & 1349 & 1421 & 1281 & 1054 \\
\hline Przerąb & 401 & - & - & - & - & $289^{c}$ & 170 \\
\hline Rozprza & 537 & 1029 & 1430 & 1069 & 1313 & 1532 & 1646 \\
\hline Ruda & 512 & - & - & 1035 & 1309 & 1239 & 1195 \\
\hline Rusiec & 634 & - & - & 1340 & 1354 & 1380 & 1335 \\
\hline Rzeczyca & 883 & - & - & 1487 & 1515 & 1532 & 1589 \\
\hline Skotniki & - & - & - & - & - & $300^{c}$ & 310 \\
\hline Sobota & 670 & 971 & 1356 & - & - & $593^{c}$ & 560 \\
\hline Sokolniki & 1096 & - & - & 1201 & 1299 & 1411 & 1211 \\
\hline Spycimierz & 535 & - & - & - & - & $487^{c}$ & 380 \\
\hline Stara Brzeźnica & 215 & - & - & - & - & - & 443 \\
\hline Stare Skoszewy & 122 & - & - & - & - & $185^{c}$ & 180 \\
\hline Szczawin & 495 & - & - & - & - & $670^{c}$ & - \\
\hline Szczerców & 1451 & 2811 & 4514 & 1479 & 2113 & 2366 & 2853 \\
\hline Świnice Warckie & 584 & - & - & - & - & 472 & 651 \\
\hline Toporów & 316 & - & - & - & - & $493^{c}$ & 558 \\
\hline Ujazd & 1220 & 1517 & 2291 & 1371 & 1524 & 1523 & 1644 \\
\hline Widawa & 2442 & 2455 & 4480 & 1272 & 1300 & 1337 & 1327 \\
\hline Witonia & 800 & - & - & 958 & 1160 & 1130 & 1116 \\
\hline Wolbórz & 2036 & 2387 & 2534 & 1686 & 2022 & 2411 & 2282 \\
\hline Żarnów & 1157 & 2036 & 3740 & - & - & 878 & 1174 \\
\hline Żytno & 904 & - & - & - & - & 800 & 678 \\
\hline
\end{tabular}

a Kursywą oznaczono dane według Słownika geograficznego..., (1880-1902), w większości z II połowy XIX w.; 1827 r.; c według Stelmacha, Maliny, Tkocza i Żukowskiego (1990).

Źródło: Jelonek (1967) - do 1910 r.; dane narodowych spisów powszechnych (z lat: 1950, 1970, 1988); Stelmach, Malina, Tkocz, Żukowski (1990); Słownik geograficzny Królestwa... (1880-1902); Powierzchnia i ludność... (2009); dane odpowiednich urzędów gmin i różne źródła internetowe (za lata ok. 2008 r.). 
2000 mieszkańców należy uznać za pewną wielkość odniesienia. Poza trzema największymi miejscowościami (Andrespol, Gorzkowice, Szczerców) wzrost zaludnienia w ostatnich latach, świadczący o zwiększaniu się roli tych miejscowości w ich otoczeniu, zanotowały m.in. Osjaków, Rozprza, Rzeczyca i Ujazd. W przypadku kilku innych (m.in. Białaczów, Burzenin, Dąbrowice, Pławno, Wolbórz) stwierdzono znaczące spadki zaludnienia.

\section{FUNKCJE, INFRASTRUKTURA I UKŁAD PRZESTRZENNY}

Do istotnych elementów branych pod uwagę podczas procedury rozpatrywania wniosku o nadanie praw miejskich należą: wskaźnik funkcjonalny wyrażony w postaci odsetka ludności utrzymującej się ze źródeł pozarolniczych (zob. tab. 2 i 5), wyposażenie w infrastrukturę techniczną (tab. 5) oraz układ przestrzenny (tab. 2). Ponadto za istotne należy uznać związki funkcjonalne miejscowości z zapleczem, czego wyrazem są funkcje centralne (tab. 5). Analizę funkcji i infrastruktury oparto na danych źródłowych pochodzących głównie ze spisu powszechnego z 1988 r. i innych źródeł z lat 1988-1990. Należy mieć świadomość, że w okresie transformacji systemowej niektóre cechy uległy dezaktualizacji - dotyczy to zwłaszcza typologii funkcjonalnej oraz poziomu wyposażenia techniczno-infrastrukturalnego. Z drugiej jednak strony określone relacje między miejscowościami rzadko ulegają rewolucyjnym zmianom (wyjątkiem może być sytuacja ekonomiczna, głównie w przypadku utworzenia lub likwidacji większych zakładów pracy). Układ przestrzenny miejscowości cechuje natomiast znaczna inercja. Liczne jednostki posiadają niemal „zamrożony” układ przestrzenny, pamiętający jeszcze czasy ich pierwszej lokacji, i powinien być on traktowany jako element dziedzictwa narodowego.

Udział ludności nierolniczej (według miejsca zamieszkania) waha się w poszczególnych miejscowościach od kilku do ponad 90\%, przy czym najwyższy (co najmniej 75\%) jest w Andrespolu, Białaczowie, Burzeninie, Gorzkowicach, Jeżowie, Lutomiersku, Lututowie, Osjakowie, Piątku, Rozprzy, Szczercowie, Ujeździe, Widawie i Wolborzu, a także w niebędącym siedzibą gminy Pławnie (tab. 5). Niskie wartości wskaźnik osiąga w Rzeczycy i Łubnicach (poniżej 50\%) oraz w Bratoszewicach i Dąbrowicach (po ok. 55\%). Rozbieżne w niektórych przypadkach informacje przekazuje opracowanie Stelmacha, Maliny, Tkocza i Żukowskiego (1990), przy czym ogólnie potwierdza ono znaczny udział ludności nierolniczej w miejscowościach większych i pełniących funkcję siedziby gminy oraz zdecydowaną dominację rolnictwa w miejscowościach najmniejszych.

Spośród 24 analizowanych miejscowości o zaludnieniu 1000 i więcej mieszkańców, 11 cechuje dominacja funkcji rolniczej (zwłaszcza: Dąbrowice, Łubnice, Ruda, Rzeczyca, Sokolniki), często też ze znacznym udziałem usług; funkcja usługowa dominuje w siedmiu wsiach (Burzenin, Jeżów, Lututów, Rozprza, Wolbórz oraz

Tabela 5. Wybrane wskaźniki miast zdegradowanych w województwie łódzkim liczących 1000 i więcej mieszkańców

\begin{tabular}{|c|c|c|c|c|c|c|}
\hline \multirow{4}{*}{ Miejscowość } & \multirow{4}{*}{$\begin{array}{l}\text { Ludność } \\
\text { nierolnicza } \\
(\%)\end{array}$} & \multirow{2}{*}{\multicolumn{2}{|c|}{ Typ funkcjonalny }} & \multicolumn{2}{|c|}{ Poziom } & \multirow{3}{*}{$\begin{array}{l}\text { Sumaryczny wskaźnik } \\
\text { miejskości }\end{array}$} \\
\hline & & & & \multirow{2}{*}{$\begin{array}{l}\text { wyposażenia techniczno- } \\
\text {-infrastrukturalnego }\end{array}$} & \multirow{2}{*}{$\begin{array}{c}\text { rozwoju funkcji } \\
\text { obsługi (centralność) }\end{array}$} & \\
\hline & & \multirow{2}{*}{1} & \multirow{2}{*}{2} & & & \\
\hline & & & & \multicolumn{3}{|c|}{ w skali 0-100 punktów ${ }^{\mathrm{a}}$} \\
\hline Andrespol & 96,9 & $\mathrm{P}$ & M1 & 60 & 44 & 57 \\
\hline Białaczów & 79,8 & RU & M1 & 29 & 43 & 37 \\
\hline Bratoszewice & 54,1 & RU & MP & 66 & 20 & 38 \\
\hline Burzenin & 86,7 & UP & $\mathrm{P} 2$ & 50 & 60 & 58 \\
\hline Dąbrowice & 55,9 & $\mathrm{R}$ & MP & 37 & 54 & 38 \\
\hline Gorzkowice & 91,4 & $\mathrm{U}$ & M1 & 67 & 57 & 60 \\
\hline Grabów & 66,5 & RU & MP & 41 & 62 & 47 \\
\hline Jeżów & 79,0 & UR & MP & 54 & 72 & 56 \\
\hline Lutomiersk & 88,4 & $\mathrm{P}$ & MP & 30 & 40 & 45 \\
\hline Lututów & 83,2 & UP & $\mathrm{P} 1$ & 56 & 72 & 62 \\
\hline Łubnice & 46,9 & $\mathrm{R}$ & MP & 55 & 42 & 39 \\
\hline Osjaków & 81,3 & $\mathrm{U}$ & P1 & 49 & 66 & 54 \\
\hline Piątek & 78,2 & PR & MP & 46 & 74 & 59 \\
\hline Pławno & 87,3 & $\mathrm{RP}$ & M1 & 56 & 12 & 34 \\
\hline Rozprza & 81,9 & UR & MP & 73 & 56 & 56 \\
\hline
\end{tabular}




\begin{tabular}{|c|c|c|c|c|c|c|}
\hline \multirow{3}{*}{ Miejscowość } & \multirow{3}{*}{$\begin{array}{l}\text { Ludność } \\
\text { nierolnicza } \\
(\%)\end{array}$} & \multirow{2}{*}{\multicolumn{2}{|c|}{ Typ funkcjonalny }} & \multicolumn{2}{|c|}{ Poziom } & \multirow{2}{*}{$\begin{array}{c}\text { Sumaryczny wskaźnik } \\
\text { miejskości }\end{array}$} \\
\hline & & & & $\begin{array}{l}\text { wyposażenia techniczno- } \\
\text {-infrastrukturalnego }\end{array}$ & $\begin{array}{c}\text { rozwoju funkcji } \\
\text { obsługi (centralność) }\end{array}$ & \\
\hline & & 1 & 2 & \multicolumn{3}{|c|}{ w skali 0-100 punktówa } \\
\hline Ruda & 72,0 & $\mathrm{R}$ & M1 & 46 & 10 & 24 \\
\hline Rusiec & 67,3 & RU & $\mathrm{MP}$ & 58 & 58 & 48 \\
\hline Rzeczyca & 43,8 & $\mathrm{R}$ & MP & 34 & 59 & 39 \\
\hline Sokolniki & 61,9 & $\mathrm{R}$ & MP & 60 & 53 & 47 \\
\hline Szczerców & 85,7 & $\mathrm{PU}$ & P1 & 52 & 66 & 61 \\
\hline Ujazd & 87,8 & PR & MP & 48 & 55 & 53 \\
\hline Widawa & 78,5 & $x$ & P1 & 61 & 62 & 57 \\
\hline Witonia & 65,3 & RU & $\mathrm{MP}$ & 50 & 43 & 43 \\
\hline Wolbórz & 75,0 & UR & MP & 66 & 67 & 61 \\
\hline
\end{tabular}

1 - Typologia ze względu na charakter dominacji funkcjonalnej: U - funkcja usługowa, $\mathrm{R}$ - rolnicza, $\mathrm{P}$ - przemysłowa, $\mathrm{X}$ - brak dominacji funkcjonalnej (równowaga trzech sektorów gospodarki) plus typy mieszane. 2 - Typologia ze względu na stosunek liczby miejsc pracy do liczby miejsc zamieszkania: $\mathrm{P}$ - przewaga funkcji miejsca pracy, MP - równowaga funkcji miejsca pracy i funkcji mieszkaniowej, $\mathrm{M}$ - przewaga funkcji mieszkaniowej.

a 100 punktów oznacza nasycenie mieszkań urządzeniami sieciowymi (wodociąg, kanalizacja, telefon stacjonarny itp.) oraz dostęp do urządzeń, takich jak oczyszczalnia ścieków, 0 punktów informuje o braku jakichkolwiek spośród tych urządzeń.

Źródło: dane NSP 1988, Sokołowski (1999) oraz dane autora niepublikowane.

Gorzkowice i Osjaków - w dwóch ostatnich samodzielnie), a przemysłowa - w pięciu. Ze względu na stosunek liczby miejsc pracy do liczby miejsc zamieszkania zdecydowanie przeważają ośrodki z równowagą miejsc pracy i miejsc zamieszkania (14 miejscowości), miejscowości o przewadze funkcji mieszkaniowej było pięć (Andrespol, Białaczów, Gorzkowice, Pławno, Ruda), podobnie jak tych z dominacją funkcji miejsca pracy (Burzenin, Lututów, Osjaków, Szczerców, Widawa). Ostatnie z wymienionych wchodziły w okres transformacji systemowej w bardziej korzystnej sytuacji; brak nowszych informacji w układzie miejscowości nie pozwala niestety na weryfikację tych danych dla współczesności.

W zakresie funkcji obsługi zaznacza się wyraźny podział na wsie gminne i pozostałe, z których ostatnie nie przekraczają wielkości wskaźnika 20 w 100-punktowej skali centralności. Spośród miejscowości wyróżniających się wysokim udziałem ludności nierolniczej Andrespol i Białaczów cechuje względnie niski poziom centralności, podobnie jak Lutomiersk, Łubnice i Witonię. In plus wyróżniają się natomiast: Piątek, Lututów i Jeżów (wskaźnik centralności >70), a następnie: Wolbórz, Szczerców i Osjaków (tab. 5, rys. 4). Uzupełnieniem znaczenia funkcjonalnego jest charakterystyka typów funkcjonalnych miejscowości w tab. 2. Większość wsi gminnych określona jest tam jako subokręgowy ośrodek usług. Na uwagę zasługuje bardzo niska kwalifikacja rangi podłódzkiego Andrespola.

Wyposażenie infrastrukturalne podlega względnie szybkim zmianom i dezaktualizuje się, jednak nawet analiza starszych danych pozwala na pewne uogólnienia. Przede wszystkim w badanej grupie nie zaobserwowano

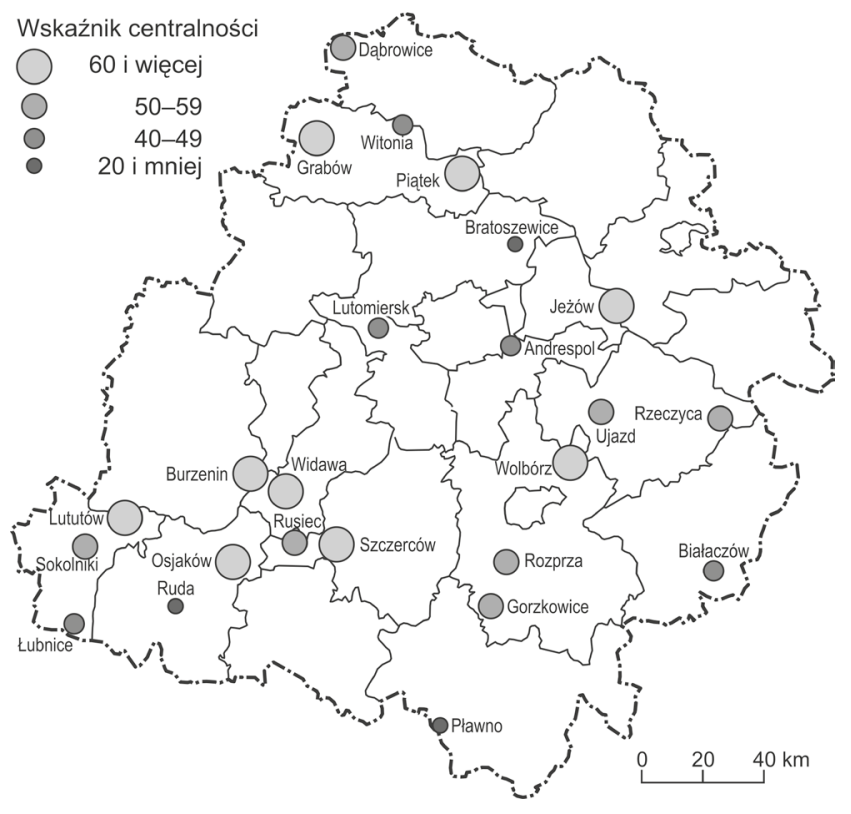

Rys. 4. Miasta zdegradowane w województwie łódzkim według wskaźnika centralności Źródło: opracowanie własne

prawidłowości polega jącej na lepszym wyposażeniu w infrastrukturę wsi gminnych. Takie miejscowości, jak: Białaczów, Dąbrowice, Grabów, Lutomiersk i Rzeczyca - wszystkie wsie gminne - cechowały najniższe wartości wskaźnika. Najlepsze warunki miały natomiast Bratoszewice, Gorzkowice, Rozprza i Wolbórz.

Czynnik morfogenetyczny ma szczególne znaczenie dla kwalifikacji miejscowości w kategorii miasto/wieś (rys. 5). Układ przestrzenny i typ fizjonomiczny badanych miejscowości przedstawiają zróżnicowane formy 


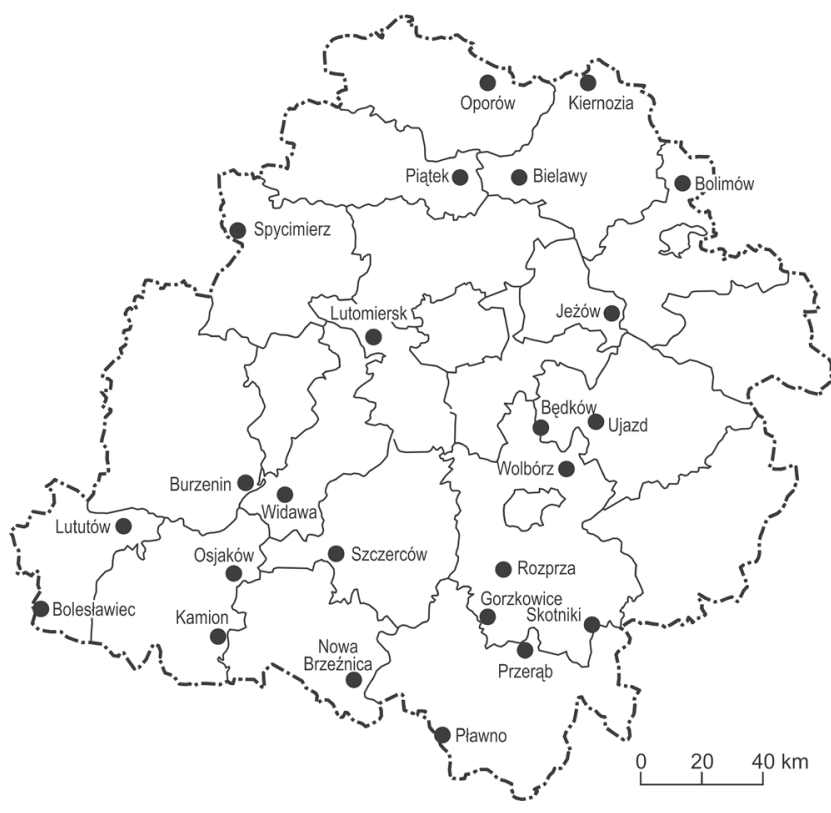

Rys. 5. Miasta zdegradowane

w województwie łódzkim

mające „miejski” lub „placowy” typ zabudowy

Źródło: opracowanie własne na podstawie danych z tab. 2

i stan. W grupie miast zdegradowanych w drugiej połowie XIX w. rozpowszechniony jest typ „miejski" - z rynkiem, charakterystycznym układem ulic i miejska, zwartą zabudową; cechuje on też niektóre (nieliczne) miejscowości, które utraciły status miasta wcześniej, jak np. Osjaków. Za podstawę charakterystyki poszczególnych miejscowości posłużyła zasadniczo klasyfikacja zawarta w pracy Stelmacha, Maliny,
Tkocza i Żukowskiego (1990), przy pewnych do niej zastrzeżeniach sugerujących potrzebę bezpośredniej weryfikacji terenowej (zob. tab. 2) ${ }^{5}$.

\section{MIASTA POTENCJALNE}

Ostatnie trzy dekady obfitowały w nadania praw miejskich w Polsce, przy czym większość nowo kreowanych miast stanowią jednostki wcześniej zdegradowane. Należy podkreślić, że zmiana statusu jest $\mathrm{z}$ reguły tylko formalnoprawnym potwierdzeniem od dawna istniejaccego stanu rzeczy. Takie atrybuty miejskości, jak: wielkość, funkcje, poziom wyposażenia infrastrukturalnego, układ urbanistyczny i morfologia, czy też stan świadomości społeczności lokalnej, która postrzega wymienione osiedla jako miasta, sprawiaja, że de facto nie stały się one miastami dopiero z chwilą formalnej zmiany statusu, lecz były nimi znacznie wcześniej.

Wyniki przeprowadzonych badań potwierdzaja, że niektóre spośród wspomnianych miejscowości odpowiadają współczesnym kryteriom miejskości. Rysunek 6 przedstawia analizowane miejscowości według wielkości sumarycznego wskaźnika miejskości uwzględniającego następujące komponenty: liczba mieszkańców, centralność, wyposażenie infrastrukturalne, funkcje gospodarcze (ludność nierolnicza, zróżnicowanie działalności). Uzupełnieniem tab. 5 (z rozdz. 5) jest tab. 6, ukazująca odpowiednie parametry w porów-

Tabela 6. Wybrane wskaźniki miast grupy porównawczej

\begin{tabular}{|c|c|c|c|c|c|c|}
\hline \multirow{4}{*}{ Miejscowość } & \multirow{4}{*}{$\begin{array}{l}\text { Ludność } \\
\text { nierolnicza } \\
\text { (\%) }\end{array}$} & \multirow{2}{*}{\multicolumn{2}{|c|}{ Typ funkcjonalny }} & \multicolumn{2}{|c|}{ Poziom } & \multirow{3}{*}{$\begin{array}{c}\text { Sumaryczny wskaźnik } \\
\text { miejskości }\end{array}$} \\
\hline & & & & \multirow{2}{*}{$\begin{array}{l}\text { wyposażenia techniczno- } \\
\text {-infrastrukturalnego }\end{array}$} & \multirow{2}{*}{$\begin{array}{c}\text { rozwoju } \\
\text { funkcji obsługi } \\
\text { (centralność ) }\end{array}$} & \\
\hline & & \multirow[t]{2}{*}{1} & \multirow[t]{2}{*}{2} & & & \\
\hline & & & & \multicolumn{3}{|c|}{ w skali 0-100 punktów } \\
\hline Kamieńsk & 86,6 & $\mathrm{RP}$ & M1 & 54 & 59 & 53 \\
\hline Rzgów & 74,9 & PR & MP & 59 & 58 & 57 \\
\hline Bobowa & 83,4 & $x$ & P1 & 55 & 73 & 60 \\
\hline Brzostek & 74,8 & $x$ & P1 & 63 & 63 & 58 \\
\hline Kołaczyce & 82,3 & $x$ & MP & 47 & 57 & 50 \\
\hline Krynki & 69,9 & $\mathrm{RP}$ & MP & 45 & 58 & 50 \\
\hline Łaszczów & 75,5 & $\mathrm{U}$ & $\mathrm{P} 2$ & 73 & 66 & 60 \\
\hline Michałowo & 77,6 & $x$ & M1 & 76 & 74 & 69 \\
\hline Przecław & 68,4 & UR & P1 & 65 & 53 & 51 \\
\hline Radłów & 80,6 & RU & M1 & 40 & 63 & 50 \\
\hline Szczucin & 81,7 & $\mathrm{P}$ & $\mathrm{P} 2$ & 56 & 78 & 66 \\
\hline Szepietowo & 90,4 & UP & P1 & 63 & 62 & 64 \\
\hline Tychowo & 62,5 & UR & $\mathrm{MP}$ & 80 & 72 & 64 \\
\hline
\end{tabular}

Objaśnienia i źródło jak do tab. 5. 


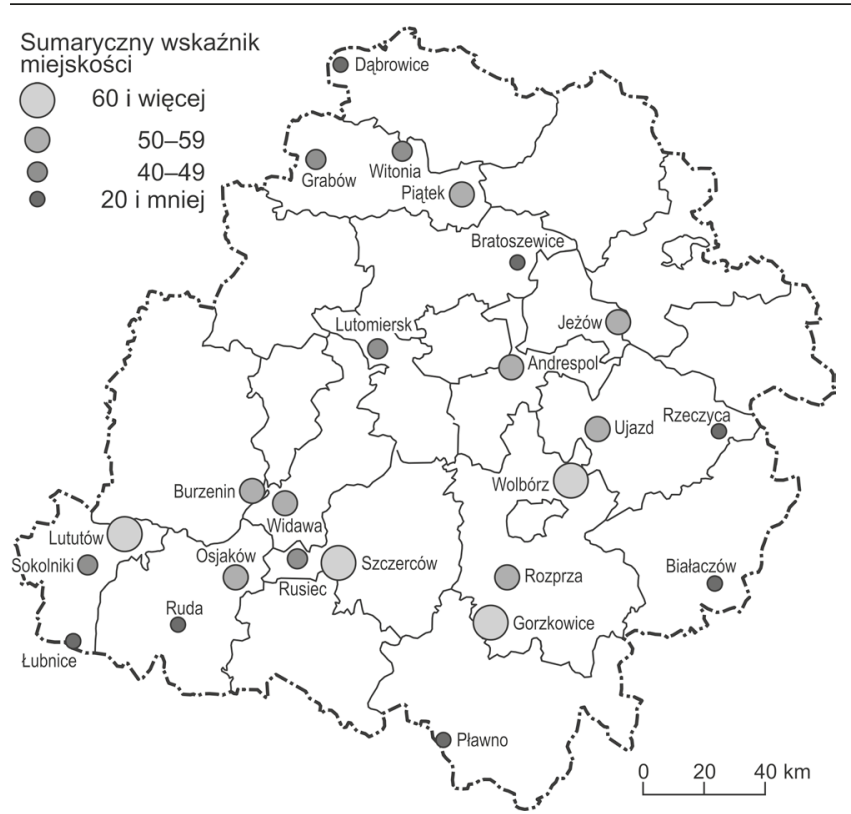

Rys. 6. Miasta zdegradowane w województwie łódzkim

według sumarycznego wskaźnika miejskości (nie uwzględnia składnika morfogenetycznego)

Źródło: opracowanie własne

nawczej grupie miejscowości, które uzyskały prawa miejskie w ostatnim czasie (dwa pierwsze wcześniej, ale są one położone na terenie województwa łódzkiego) $\mathrm{Na}$ jej podstawie otrzymujemy potwierdzenie, że takie miejscowości, jak: Wolbórz, Szczerców, Gorzkowice, Lututów, Piątek, a w dalszej kolejności Burzenin, Widawa, Jeżów, Rozprza, Ujazd, Andrespol i Osjaków, spełniają większość kryteriów wymaganych współcześnie przy nadawaniu praw miejskich. Niektóre z tych miejscowości nie spełniają wszystkich warunków, np. Andrespol nie ma wykształconego typowo miejskiego układu urbanistycznego, a kilka innych nieosiaga zaludnienia 2000 mieszkańców, co w praktyce nadawania praw miejskich nie musi stanowić przeszkody dyskwalifikującej6.

\section{ZAKOŃCZENIE}

W wieku XIX w małych miastach dominowały funkcje usługowe, głównie handlowa, wraz z drobną wytwórczością i rolnictwem. Małe miasta były ogniwem pośrednim między wsią i większym miastem, odgrywały przy tym rolę integrującą dla okolicznych terenów wiejskich. Częste kontakty między wsią i małym miastem umożliwiała przede wszystkim gęsta i względnie regularna sieć miejska, uwarunkowana przede wszystkim dostępnością komunikacyjną.

Obecnie dostępność komunikacyjna nie stanowi istotnej bariery, dlatego małe miasta są często pomijane na drodze: miejsce zamieszkania (wieś) $\rightarrow$ miejsce pracy, zakupów, realizacji potrzeb kulturalnych itp. (duże lub średnie miasto). W wielu miejscowościach zanikły tradycyjnie pełnione funkcje produkcyjne (drobna wytwórczość), a w niektórych także funkcje usługowe; niektóre z nich uległy też częściowemu wyludnieniu, a miejska zabudowa - degradacji. Są to przyczyny - pomijając sytuację makroekonomiczną - kryzysu małych miast. Zanik drobnej wytwórczości wiąże się m.in. ze wzrostem znaczenia produkcji masowej we współczesnym świecie, a także z doktrynalną walką z własnością prywatną (uosabianą przez niewielkie zakłady produkcyjne i usługowe), która była praktyką w ponad 40-letniej historii PRL-u. Drogą do odrodzenia małych miast powinno być przywrócenie niektórych spośród tych funkcji. W okresie transformacji systemowej rozwój drobnej i średniej przedsiębiorczości realizowany był w poszczególnych ośrodkach z różnym powodzeniem.

Odmiennie przedstawia się kwestia funkcji standardowych. Miejsce centralne powinno mieć swój własny obszar obsługi i określoną liczbę obsługiwanej ludności, co wiąże się z minimalnymi wielkościami popytu na dobra i usługi. Zbyt mały popyt czyni lokalizację określonych placówek usługowych nieopłacalną. Spowodowało to zanik funkcji centralnych w niektórych miasteczkach i w rezultacie upadek wielu miasteczek położonych zbyt blisko silniejszych ośrodków konkurencyjnych. Wydaje się, że mają one niewielkie szanse na odrodzenie i restytucję praw miejskich. Dotyczy to szczególnie tych, które aktualnie nie pełnią funkcji ośrodka gminnego.

Miejscowości, które utraciły prawa miejskie na mocy dekretu carskiego z 1869 r. są zwykle dużymi wsiami gminnymi, o dobrze rozwiniętej infrastrukturze, strukturze funkcjonalnej i funkcjach pełnionych względem wiejskiego zaplecza (centralność), a także o miejskim układzie przestrzennym. Miejscowości, które zostały zdegradowane przed połową XIX w. są odpowiednio mniejsze (liczą one zwykle poniżej 500 mieszkańców) i poza nielicznymi wyjątkami nie posiadają cech miejskich; także ich ranga administracyjna jest zazwyczaj niska (nie są siedzibami gmin).

\section{PRZYPISY}

\footnotetext{
${ }^{1}$ Artykuł ukazał się w pracy zbiorowej pod red. S. Kaczmarek (2011).

${ }^{2} 1$ stycznia 2011 r. prawa miejskie uzyskał Wolbórz w województwie łódzkim (przyp. redakcji).

${ }^{3}$ Nie można wykluczyć, że rzeczywista liczba jednostek tej kategorii jest w rzeczywistości nieco większa (lokacje nieudane bądź prawa miejskie niepotwierdzone).

${ }^{4}$ Są to: Biskupie - część miasta Piotrków Trybunalski, Brus - część miasta Łódź, Czekaj - część miasta Zduńska Wola, Grocholice - część miasta Bełchatów, Kolumna - część miasta Łask, Łąkoszyn - część miasta Kutno, Łowicz Nowe Miasto - część
} 
miasta Łowicz, Nowy Wieruszów - część miasta Wieruszów, Podzamcze - część miasta Wieruszów, Ruda Pabianicka - część miasta Łódź, Stary Wieruszów - część miasta Wieruszów, Wielka Wieś - część miasta Piotrków Trybunalski. Do powyższej kategorii zaliczono również Karsznice, które miały status osiedla w latach 1959-1972 i w 1973 r. zostały podzielone. Większą ich część włączono do miasta Zduńska Wola, mniejsza pozostała wsią w gminie Zduńska Wola.

${ }^{5}$ W opracowaniu Stelmacha, Maliny, Tkocza i Żukowskiego (1990) w licznych przypadkach typy „miejski” i „placowy” są wyraźnie mylone. Bogaty materiał porównawczy zawiera praca Kuleszy (2001).

${ }^{6}$ Wskazują na to przykłady z ostatnich lat, kiedy prawa miejskie uzyskały jednostki osadnicze pozbawione miejskiego układu przestrzennego (np. Czarna Woda, Glinojeck, Siechnice) i o zaludnieniu wynoszącym zaledwie 1,1-1,4 tys. osób (np. Krynica Morska, Kleszczele, Frampol, Zaklików, Przecław, Kołaczyce).

\section{BIBLIOGRAFIA}

Drobek, W. (1999). Rola miast zdegradowanych w sieci osadniczej Ślaska. Opole: Państwowy Instytut Naukowy -Instytut Śląski w Opolu.

Jelonek, A. (1967). Ludność miast i osiedli typu miejskiego na ziemiach Polski od 1810 do 1960 r. Dokumentacja Geograficzna, 3-4.

Kaczmarek, S. (2011). Miasto. Księga jubileuszowa w 70. rocznice urodzin Profesora Stanisława Liszewskiego. Łódź: Wydawnictwo Uniwersytetu Łódzkiego.

Kulesza, M. (2001). Morfogeneza miast na obszarze Polski środkowej w okresie przedrozbiorowym. Dawne województwa łęczyckie i sieradzkie. Łódź: Wydawnictwo Uniwersytetu Łódzkiego.
Miasta polskie w tysiacleciu (1967). Wrocław-Warszawa-Kraków: Ossolineum.

Powierzchnia i ludność w przekroju terytorialnym w 2009 r. (2009). Warszawa: Główny Urząd Statystyczny.

Rosin, R. (1959). Studia z dziejów miast dawnych województw łęczyckiego i sieradzkiego (XII-XVI w.). Sprawozdania z Czynności i Posiedzeń Łódzkiego Towarzystwa Naukowego, XIV Rosin, R. (1971). Miasta regionu łódzkiego. Próba periodyzacji dziejów. Region Łódzki. Studia i Materiały, 1.

Słownik geograficzny Królestwa Polskiego i krajów słowiańskich (18801902). Oprac. F. Sulimierski, B. Chlebowski, W. Walewski. Warszawa.

Sokołowski, D. (1999). Zróżnicowanie zbioru małych miast i większych osiedli wiejskich w Polsce w ujęciu koncepcji kontinuum wiejsko-miejskiego. Toruń: Wydawnictwo Naukowe Uniwersytetu Mikołaja Kopernika.

Sokołowski, D. (2008). Miasta nowe i potencjalne jako główne elementy kontinuum wiejsko-miejskiego w Polsce. W: A. Jezierska-Thöle, L. Kozłowski (red.), Gospodarka przestrzenna w strefie kontinuum miejsko-wiejskiego (s. 63-78). Toruń: Wydawnictwo Naukowe Uniwersytetu Mikołaja Kopernika (s. 63-78).

Statystyka miast i osiedli 1945-1965 (1967). Statystyka Regionalna. GUS, 6 .

Stelmach, M., Malina, R., Tkocz, J., Żukowski, B. (1990). Obszary wiejskie i grunty rolnicze w Polsce. Wrocław: Instytut Planowania i Urządzania Terenów Wiejskich, Akademia Rolnicza we Wrocławiu.
Artykuł wpłynął: 18 marca 2018 Zaakceptowano do druku: 8 grudnia 2018 